\title{
Finnish Studies on Islam: Themes and Approaches
}

\author{
TUULA SAKARANAHO \\ University of Helsinki
}

\begin{abstract}
In recent decades, Finnish research on Islam has started to expand rapidly; in the process, it has also widened to disciplines which previously did not necessarily focus on the study of religions. The article provides an overview of the range of these studies, conducted by Arabists, comparative religionists, theologians, anthropologists, and social scientists, with a close focus on the central themes and main methodological approaches used in these studies. The article is divided into four parts. In order to give some historical background to recent studies on Islam, the first part takes a quick look at the explorations of Georg August Wallin and the social-anthropological studies of Edvard Westermarck and Hilma Granqvist. Contemporary research is divided according to its main topic of interest into the following three parts: studies on the foundational sources of Islam and subsequent theological questions; studies on Muslims in Muslim populated countries; and studies on Muslims in Europe and Finland. In the concluding remarks, the article considers some of the challenges posed by the current social and political situation for research on Islam and Muslims.
\end{abstract}

Keywords: Islam, Muslims, Finland, study of religions, Islamic studies, theology, anthropology, ethnography, media studies, international politics

In recent decades research on Islam has expanded rapidly in Finland, in the process widening to disciplines which previously did not necessarily focus on the study of religions. This increase in research on Islam is of course part of a larger development, whereby religion has become a highly fashionable research topic outside its traditional realms of theology and Comparative Religion. Of all the world religions, Islam in particular has started to attract scholarly attention in a wide field, due undoubtedly to its growing visibility and significance in world politics, and to the consequent interest on the part of research-funding organizations in financing studies which can shed light on the role of Islam in the contemporary world. One of the positive effects of this trend is the extent of research on Islam currently being conducted in different disciplines in Finland. 
The purpose of this article is to bring under close scrutiny the variety of Finnish studies on Islam, conducted by Arabists, comparative religionists, theologians, anthropologists, and social scientists, with a focus on the central themes and main methodological approaches used in these studies. Thus, the overall time span outlined thereby runs from the nineteenth century till the present time. The main emphasis, however, is placed in contemporary studies. ${ }^{1}$ In general, one can agree with the observation of Buijs and Rath $(2006,2)$ that '[the] development of the study of Islam is to a certain extent contingent on the local situation'. The studies covered here thus in a way constitute a mass of information about Islam in Finland, dealing with a variety of issues, revealing different motives and interests, and pursuing a diverse sets of goals. In short, these studies discuss Islam from at least three perspectives: Islam per se, Islam in different geographical locations, and 'Islam in migration' (cf. Buijs \& Rath 2006, 3). These different approaches to the study of Islam also inform the structure of this article.

Before going into details of individual studies, some definitions of the terms 'Islam' and 'Muslim' are in place. These terms are at present highly contested, and a great deal of energy is consumed in the debate over their proper meanings. ${ }^{2}$ This article opts for a fairly practical approach: both 'Islam' and 'Muslim' are understood as topics of research, which are assigned different meanings according to the particular scholar's research focus and disciplinary position. From the point of view of the study of religions, Islam is one of the world religions; its geographical scope extends from Morocco to the Philippines, and it is estimated to have around 1.5 billion adherents. ${ }^{3}$ Simply put, Islam is one of the monotheistic Abrahamic religions, and in the course of its history since the seventh century has evolved into a variety of religious, philosophical and legal schools. Since the time of its founder, the Prophet Muhammad, it has also been intertwined with politics in a variety

1 I sincerely thank the two anonymous readers, who reviewed this article for Temenos, for their valuable comments and suggestions of necessary corrections. This article is partly based on my two previously published articles, one in French (Sakaranaho 2003), the other in Finnish (Sakaranaho 2008a). It is, however, updated in light of the most recent studies on Islam and to some extent rewritten with the critical comments of the above-mentioned readers in mind. Any possible mistakes in this article are of course entirely mine.

2 This, of course, also concerns the overall definition of religion in relation to diaspora and globalization. For the recent discussion on the topic, see McLoughlin \& Zavos (forthcoming in 2011).

3 See http://www.religioustolerance.org/isl_numb.htm, which estimates that Islam is the second largest religion in the world after Christianity and is growing by about 2.9 per cent per year, which is more than the annual increase in the total world population ( 2.3 per cent). If the current trend continues, Islam will be the most popular world religion by the mid-21st century. Islam is the second largest religion in Europe as well (Hunter 2002). 
of ways. (See Smart 1998; Waines 2002; Urubshurow 2008; see also Rippin 2006.) Consequently, it is impossible to say what Islam actually is. For the scholar of religions, however, it is not necessary to know what 'authentic' Islam might be, but to approach it as a historical and social construction, vested with different meanings by different people, situated in different times and places. This is how Islam is approached in this article. Similar difficulties are of course attached to the term 'Muslim', which currently is very much a matter of debate in Europe in particular (see Sakaranaho 2006, 206-213). In this article, I opt for a simple but at the same time fairly broad sociological definition of a Muslim, as a person whose religious or cultural background is in Islam (see House 1996, 221; Marechal 2003, 8ff; Jeldtoft 2009). This definition does not necessarily say anything about a person's religious conviction or about the level of their religiosity. The problematization of the term 'Muslim' is of course very important right now, but that is not my focus here (see JEMS 2009; Sayyid \& Vakil 2010); the purpose of the article is simply to describe the current state of research on Islam and Muslims conducted in Finland over recent decades. ${ }^{4}$

The article is divided into four parts. In order to give some historical background to recent Finnish studies on Islam and Muslims, I first take a quick look at the explorations of Georg August Wallin and the socialanthropological studies of Edvard Westermarck and Hilma Granqvist, all of whom continue to attract wide interest today. They can be seen as the predecessors of contemporary ethnographic research, which emphasises the importance of fieldwork among the people studied. The place of Westermarck and Granqvist among the Orientalists in Finland has been debated, but this debate, and that over Finnish 'Orientalism' in general, is a topic more thoroughly discussed elsewhere and falls out the scope of this article (see Aalto 1971; Kantokorpi 1984; Isotalo 1995; Juusola 2011). Contemporary research, which has been conducted in Finland during the second half of the 20th century and at the beginning of the 21st, will be divided according to its main topic of interest into three parts, as follows: studies dealing with the foundational sources of Islam and subsequent theological questions; studies of Muslims in Muslim-populated countries; and studies of Muslims and Islam in Europe and Finland. Finally, in the concluding remarks, I consider on the challenges posed by the current social and political situation for research on Islam and Muslims.

4 For a somewhat similar approach, see e.g. Nielsen 1995 (third edition 2004); Maréchal, Allievi, Dassetto \& Nielsen 2003; Buijs \& Rath 2006; Maussen 2007; see also Jeldtoft (2009) discussing the Yearbook of Muslims in Europe. 


\section{Three Pioneers: Wallin, Westermarck, and Granqvist}

'The Arab world has had a capacity for drawing to it from western Europe a number of remarkable men and several no less remarkable women' (Mead 1979, vii). Georg August Wallin, Edvard Westermarck and Hilma Granqvist are undoubtedly good examples of such 'remarkable men', and the 'no less remarkable women', who ventured over a century ago to North Africa and the Middle East.

Perhaps one of the most famous explorers of Arabia in Finnish history was Georg August Wallin (1811-1852). In the 1840s, he undertook altogether three expeditions to Arabia. In recognition of his explorations, and for being the first European explorer ever to cross northern Arabia, he was rewarded both by the Royal Geographic Society in London and by the Société de géographie in Paris (see Mead 1958; Mead 1979). The Royal Geographic Society also published the reports of his journeys. As one important outcome of his expeditions, Wallin was the first European scholar to publish specimens of the Bedouin poetry of the Arabian Peninsula. Unfortunately, Wallin died at the early age of 41 , and only a small amount of his research has therefore been published. His diaries include a great deal of information about the lives of Bedouins. These writings, however, have not become internationally known, due in part to the language barrier; after all, Wallin wrote his diaries in Swedish. A fair number of his texts were published in the nineteenth century and at the beginning of the twentieth by S. G. Elmgren and Knut Tallqvist, but it is only since 2010, for the first time, that publication of the entire body of Wallin's writings (by the Society of Swedish Literature in Finland) has begun, ultimately comprising six volumes (see Öhrnberg \& Berg \& Pihlflyckt 2010). Moreover, Wallin's 'spiritual inheritance' has been kept alive and continued by subsequent generations of Finnish scholars; thus for instance the annual general meeting of the Finnish Oriental Society is held on his birthday, on 24 October. (Öhrnberg 1995, 36-39; Mead 1958, 3; 1979, viii.)

To properly understand the significance of Wallin's expeditions, we have to see him in terms of his own time. As Kaj Öhrnberg $(1995,26)$ has put it, Wallin's expeditions to the Arabian Peninsula, Persia and the Levant were more of a romantic adventure than serious academic exploration of Arabia. Of course he was not alone not in this. As we well know, the European imagination of the eighteenth and nineteenth century created the Orient as an exotic world of daydreams and erotic escapism. Along with European colonialism and the 'white man's burden' to colonize the rest of the world, there were others: those who were seeking peoples who had 
not been touched by western civilization and hence would fit the ideal of a 'noble savage', popularized in Europe by Rousseau. What could be more attractive than the freedom-loving Bedouins, living under the skies of the Arabian desert? In anthropological terms, Wallin was an example of an explorer who 'went native'; while in the Middle East, he dressed as an Arab and presented himself as Muslim; what is perhaps most surprising, he seems to have accomplished this change of habitus perfectly. Above all he enjoyed living among the 'ordinary people' and, in his letters expressed his love for the Bedouins in particular. At the same time he was highly critical of Islam, which he saw as the main reason for the degradation of the Arab Muslim world, suffering under the faltering Ottoman Empire; he also nurtured some very negative stereotypes of the Arabs, Turks, Persians and Kurds whom he met on his travels. These remarks notwithstanding, his diaries offer interesting insights into the Bedouin way of life, the relationships between the Arab culture and other cultures in the area, and the relationships of the Bedouins with urban populations. (Öhrnberg 1987, 32-43; 1995, 39-43; Aro 1979.)

In Finland, it was very much Wallin's representation of Oriental life that formed the picture of the Orient held by educated Finns of his time. Among academics, however, his work met with criticism. His expeditions were unfavourably compared for example to those of Mathias Alexander Castrén (1813-52) to Siberia, where he studied Finno-Ugric peoples. Naturally enough, Wallin's travels did not have the same implications for the rising Finnish nationalistic ethos as did Castrén's research among peoples of Finno-Ugric stock. However, after returning to Finland in 1850 Wallin was appointed to the Chair of Oriental languages in the University of Helsinki. In the Finnish academic world, Wallin was very much a loner, who did not respect Wilhelm Ross (1718-1766) and Peter Forsskål (1732-1763) renowned scholars of Arabic studies at the Academy of Turku, long before Wallin's time - as his predecessors. ${ }^{5}$ Wallin did not create a school of study at the University of Helsinki, nor did he have any followers in his research. One reason may have been lack of time; he held his chair for only two years before his sudden death. (Öhrnberg 1987, 43-7; 1995, 39-43.)

5 Arabic studies in Finland started in the 17th century with the foundation of the Academy of Turku, where Arabic was taught already in the 18th century. Wilhelm Ross (1718-1766) and Peter Forsskål (1732-1763) were scholars at this Academy (see Öhrnberg 1987, 27-8). In 1760, Peter Forsskål was appointed by the Danish King Frederick V to an expedition to Arabia, where he took extensive notes on various species of plants and animals, later published by Carsten Niebuhr. 
At the beginning of the twentieth century, Finnish interest in Arabic peoples as exemplified in Wallin's explorations was broadened into the discipline of social anthropology by Edvard Westermarck and Hilma Granqvist, who pioneered internationally significant fieldwork in different regions of Mediterranean: Westermarck in Morocco and Granqvist in Palestine.

It is hard to sum up the scholarly achievements of Edvard Westermarck (1862-1939) in a few words; even more difficult to give a full assessment of his work, which has been evaluated by many scholars, in Finland and elsewhere. Indeed, we have to admit that 'questions concerning scholarly influence are notoriously difficult to answer' (Pipping 1982, 355). In any case, Westermarck is probably the Finnish scholar with the greatest international, reputation, or at least one of them (Allardt 1984, 5). In Finland, Westermarck is recognized as a kind of 'mythical forefather in Finnish sociology and anthropology' (Siikala 1998, 7). Accordingly, Finnish sociologists have named their association the Westermarck Society, while the Finnish Anthropological Society has since 1982 held an Edvard Westermarck Memorial Lecture Series (Allardt 1998, 116; Siikala 1998, 7). Moreover, Westermarck is also admired in Finland for his work in the field of philosophy (Numelin 1941, 268; Wright 1982, 26). In general, however, it has been argued that he was scientifically 'somewhat liminal and hard to place' (Siikala 1998, 7; see also Pipping 1982, 353).

With respect to his academic career, Westermarck held three chairs of the professorship. His first appointment was as Professor of Moral Philosophy at the University of Helsinki (1906); his second as Rector and Professor of Philosophy at Åbo Akademi University in Turku (1918-1933); his third, parallel to his posts in Finland, as Professor of Sociology at the University of London (1914-1935). At the end of the 1890s and in the early twentieth century he published world-famous monographs that have become classics of a sort: The History of Human Marriage (1891), The Origin and Development of the Moral Ideas I-II (1906-08), Ethical Relativity (1932), and Early Beliefs and Their Social Influence (1932). In addition to these works of general anthropological interest, Westermarck published extensively on his work on Morocco, which cannot all be listed here (see Westermarck 1914; 1926; 1930; see also Suolinna \& af Hällström \& Lahtinen 2000).

Surprisingly enough, Westermarck has been portrayed as an armchair anthropologist - despite his extensive fieldwork in Morocco, where, beginning with his first field trip in 1897, he spent at different times a total of ten years (see Stroup 1982, xi; Numelin 1941, 275). This paradox is perhaps justified in the sense that Westermarck's scholarly interests were divided 
between theoretical and practical issues. On the one hand, he pondered questions of human evolution, on the other he studied the life of Moors and Berbers in Morocco. One of his main scholarly aims was to identify the psychological and biological foundations of cultural and social customs, such as marriage, beliefs or ritual practices. In philosophy, he was oriented towards empiricism and evolutionary theory, Charles Darwin (1809-82) having had a great impact on him. It is therefore not surprising that recent interest in evolutionary psychology has made his work timely for the present generation. (Siikala 1998, 10.) However, the evolutionary views and the comparative method utilized by Westermarck have been criticized both by his own contemporaries and by present-day scholars (Pipping 1982, 351). Émile Durkheim (1858-1917), for instance, deplored Westermarck's interest in the evolution theory and questioned his broad assumptions based on comparison (see Allardt 1998, 117). Recently, it has been argued that he did not develop any deep expertise in the field of psychology and biology, and that his training in philosophy was rather limited. ${ }^{6}$ From the sociological point of view, his reluctance to consider cultural or social wholes, and hence his focus on isolated, unconnected cultural features, beliefs and rituals, has been questioned. (Allardt 1998, 117; Pipping 1982, 353.)

As against this substantial criticism, on the other hand, it has been said that Westermarck should not be disregarded as 'just one of those 19th century evolutionists' (Pipping 1982, 348). It is pointed out that biological reductionism operated for Westermarck simply as a background theory or as a general framework, to be revised and corrected from the sociological and anthropological point of view (Stroup 1982, xiv). ${ }^{7}$ In other words, Westermarck did not view as mutually incompatible the 'evolutionary school', with is comparative focus on biological effects in social and cultural life, and the 'ethnological school', with its focus on migration, cultural encounter and exchange. Ideally, his aim was to utilize both of these approaches in his research. Moreover, later in life Westermarck himself expressed criticism against the comparative method, which took phenomena out of their context and classified them according to types. (Numelin 1941, 273-4.) The questions he raised concerning human existence and the complex relationships between cultural, social, psychological, and biological factors have in no way lost their significance for present-day scholarship (Siikala 1998, 10; see also Numelin 1941, 272; Nisula 1994, 18).

6 For his lectures in psychology, see Ihanus 1990, 146-52; for his philosophical reading, see von Wright 1982, 27.

7 For the defence of Westermarck, see Stroup 1982, xi-xiv. For Westermarck's view on Durkheim, see Melasuo 1995, 59. 
Along with Franz Boas (1858-1942) and Pitt Rivers (1827-1900), Westermarck was one of the first anthropological scholars to conduct full-time fieldwork. Fieldwork among the Moors and the Berbers gave him a clear personal perspective on the study on ethnological problems, and the data he collected naturally also operated as a foundation for his theories concerning human behaviour. (Numelin 1941, 275.) He also insisted that the fieldworker had to be familiar with the language of the informants. In the field, he utilized the help of informants and carried out half-structured interviews. He was also very careful in ensuring the reliability of the information given to him in the course of interviews. However, he did not give any comprehensive account of the methods he used in his fieldwork. (Pipping 1982, 353-4.) This is probably why he has been overshadowed by his student at the London School of Economics, Bronislaw Malinowski (1884-1942), whose studies of the Trobriand Islanders revolutionized anthropological fieldwork. Malinowski himself greatly admired Westermarck's gigantic study, The History of Human Marriage, and described his lectures as 'respectable and admirable' (Malinowski 1960, 25). However, Malinowski $(1960,183)$ did not see Westermarck as one of the chief initiators of fieldwork, but rather saw his position in ethnology as a follower of the approach of James Frazer (1854-1941).

As against this reading, with its focus on the development of British social anthropology, it has been noted that Westermarck's Finnish background pointed his interests, unlike those of his British colleagues, not toward the study of 'savages' but toward folklore, which at the time was flourishing as part of the Finnish nationalistic ethos. Thus an interest in folklore might be seen as one incentive behind Westermarck's research, even though he did not identify with the nationalistic project of Finnish folklore. (Siikala 1998, 8-9; cf. Pipping 1982, 353.) Like his predecessor Georg August Wallin, Westermarck's 'field' was too remote from the study of peoples of FinnoUgric stock.

But travel abroad, and the exploration of unfamiliar cultures, has not been a purely male prerogative in Finnish scholarship. In the 1920s, Hilma Granqvist (1890-1972) applied for a fellowship to study archaeology in Jerusalem, and to collect material for her doctoral thesis on women in the Old Testament. During her stay in Palestine she lived in the small village of Artas, where she had a chance to get to know the local people; this sparked an interest in studying their Muslim way of life. (Weir 1972, 234; Rissanen 1977,39 .) Granqvist started fieldwork in Artas in 1925, lasting for twenty months. This fieldwork resulted in an extremely meticulous ethnographic description of the marriages contracted in the village over a period of 
one hundred years. Based on this information, she compiled family lists and constructed genealogical trees, which were then supplemented with statistics and tables. In gathering information she used the help of village informants; these were two elderly women, who thus had long experience of life in the village. (Frankenhaeuser 1981, 49.) The results of this research were published in two volumes, entitled Marriage Conditions in a Palestinian Village I (1931) and II (1935); the first volume was accepted as Granqvist's doctoral thesis at Åbo Akademi by Professor Edvard Westermarck (see Westermarck 1937; Isotalo 1995).

In her work, Granqvist followed the tradition of village anthropology, which was very new in Finland at the time. In light of the difficulties that Granqvist faced in pursuing her academic career after gaining her doctorate, it is obvious that her work was not valued in Finland. On the contrary: she was rejected by her contemporary professors at the University of Helsinki, which hampered her in her academic career for the rest of her life. (See Widén 1995.) As against the lack of appreciation for her work that she suffered in Finland, elsewhere Granqvist's research was held in high esteem; her detailed studies of village life were mentioned for instance by Edward Evans-Pritchard (1902-1973), as exemplary models of how anthropological fieldwork should be conducted. Financially, Granqvist was supported by fellowships from the United States and Sweden, enabling her to continue her fieldwork at Artas. This work resulted in three more volumes, published in English, on birth and childhood among the Arabs as well as on Muslim death and burial. In 1951, two of her publications - Birth and Childhood among the Arabs (1947) and Child Problems among the Arabs (1950) - were recognized in American Anthropologist by Margaret Mead, who admired in Granqvist's work 'the fidelity of an ethnologist to her material'. Granqvist's last publication, Muslim Death and Burial (1965), has been of special interest to historians of religion (Rissanen 1977, 41).

It is hard to say what impact Hilma Granqvist might have had in the field of anthropology in Finland had she not been barred from a university career. Her gender and nationality undoubtedly operated against her. As a woman it was hard for her to gain academic recognition either in Finland or abroad, and as a Finn she was marginal on the international anthropology scene. Her work is valuable, however, as a unique study of Arab Muslim life, more particularly as one of the few studies of its kind conducted in Palestine before the turmoil of 1948. (Weir 1972, 235; Seger 1981.) The present-day political situation in Palestine gives her work additional interest, in that it brings to life a world that once existed there. Granqvist has in fact recently 
been re-discovered in Finland; I might mention, for example, the exhibition of her photographs from Artas, displayed in Helsinki in the autumn of 2001.

\section{Contemporary Studies of Islam}

It is more than a hundred and fifty years since Georg August Wallin's expeditions to Arabia. His command of the Arabic language and his interest in Islam was continued by successive generations, which, however, cannot be traced here comprehensively. In general, the progress of Arabic and Islamic studies in Finland has depended very much on the personal interest of individual professors (Öhrnberg 1993, 25). Today, Arabic studies are well established at the University of Helsinki and research on the Arabic language and literature is flourishing in Finland (Palva 1995; 2001; Öhrneberg 1993). ${ }^{8}$

Contemporary Finnish scholars live in a world that is culturally and socially completely different from that of the nineteenth century. With the growing visibility and significance of Islam in world politics during recent decades, Finnish research on Islam has started to expand rapidly. Academics are asked to 'explain' phenomena that are related to Islam and thus make Islam comprehensible to a wider audience. Thus research carried on in Finland is answering the growing needs of various sectors of society for reliable and impartial information on Islam. In general, the scholarly literature on Islam has increased greatly in recent times. This can be seen as a reflection of 'a more general interest in religions within European cultures' (Melasuo 1993, 29). It is quite another matter, however, whether this increase in the literature will also deepen our understanding of the Muslim world, as anticipated by eminent scholars such as Maxime Rodinson (1980, in Melasuo 1993, 30).

In a sense, one of the most fundamental undertakings in the study of Islam is to make the Qur'an available in the vernacular. The first translation of the Qur'an into Finnish was published by a Turkish Tatar Muslim, Ahsen Böre, in 1942 (see Böre 1942); the first translation from the original Arabic was completed by Jussi Aro, Armas Salonen and Knut Tallqvist in 1957, and a more recent one by Jaakko Hämeen-Anttila in 1995. Hämeen-Anttila has also published an introduction to the Qur'an that 'aims at guiding the Finnish reader into the world of the Qur'an and to present the holy book of Islam in as many-sided a manner as possible' (Hämeen-Anttila 1997a; see also 1997b). In addition, he has published a university-level textbook

8 For important studies in Arabic and Islamic studies outside the university, see Öhrnberg 1993, 27. 
on different forms of Islam, past and present. In his work, Hämeen-Anttila (1999) aims at presenting the plurality of Islam, inherent in the Sunni and Shiite division and in particular in the variations of different sects within Shiism. His purpose is to give a more complex view of Islamic traditions than is normally the case in Finnish writing on Islam. In his emphasis on religious minorities rather than the majority, Hämeen-Anttila's purpose is to problematize definitions of 'authentic' Islam. ${ }^{9}$

In addition to the Qur'an, Finnish scholars have also studied the Islamic tradition more generally, in relation to Islamic medicine (Perho 1995) and Sufism (Hallenberg 1997; Hämeen-Anttila 2002). With respect to Sufism, Hallenberg and Perho have published a collection of the aphorisms and ideas of the Sufi mystics, active from the seventh to the thirteenth century. In this work, they describe the mystical tradition of Islam, exemplified in asceticism and martyrdom, and give examples of mystical elements in the life of the Prophet. (Hallenberg \& Perho 1992; cf. Melasuo 1993, 31.) The tradition of the Prophet Muhammad has also been studied by Sylvia Akar (2006), who in her doctoral dissertation looked at the concept of choice in Sahih al-Bukhari. Religious factions in Islam, inherited from the past but transmitted by different generations down to the present time, are exemplified in the genealogy of Fatima, edited by Kaj Öhrnberg. In his introduction, Öhrnberg (1983, ix-x) draws attention to the political and social relevance of Muslim religious discussion among the Shiites, for whom arguing about the past seems to be a way to discuss contemporary politics.

A decade ago, Heikki Palva and Irmeli Perho completed a major work, editing a general presentation of Islamic culture. This volume covers a wide range of topics, including the everyday life of Muslims, Arabic language, literature and music, the history of Islam and new revivalist movements, Islam in Africa and Asia, and learning, art and architecture in Arab-Islamic culture. (Palva \& Perho 1998.) As such, this work is a valuable contribution to the contemporary Finnish literature on Islam; due to its emphasis on history, however, its geographical focus is almost entirely on the Arab-Islamic area.

In addition to these studies, Islam has also been a topic of interest among scholars of theology at the University of Helsinki. The biblical scholar Heikki Räisänen, for instance, wrote on Qur'anic theology already in the 1970s (Räisänen 1971), and compared Islam with Christianity (Räisänen 1972). In the 1980s he published a book for a general audience, in which he looked at Islam and Christianity in parallel. Using Islam as a mirror can in

9 Jaakko Hämeen-Anttila is a prolific writer; in addition to the works mentioned above, he has also produced several translations on Islamic literature, which cannot all be listed here. 
Räisänen's view help us to better understand Christianity (Räisänen 1986). A decade later, Räisänen (1997) published a series of lectures on the interaction between Islam and Christianity, with the aim of demonstrating ways in which a Biblical scholar can take part in a dialogue between religions and worldviews. A timely debate on religious dialogue was also one topic of Esko Kähkönen's doctoral research on Muslim-Christian dialogue in Germany (2000). The same topic has been studied from a historical point of view by Seppo Rissanen (1993) in theology and by Teuvo Laitila (2001) in cultural anthropology. The most recent study on Christian-Muslim dialogue in the field of Systematic Theology is the work of Heidi Hirvonen (2010) on four Lebanese thinkers, two of them Muslim and two Christian. In addition to religious dialogue, certain aspects of Islamic theology have also attracted the interest of Finnish theologians: Ari Hukari's (2005) recent doctoral dissertation compared the views of Abdul A'la Mawdudi and Fazlur Rahman on the relationship between divine revelation and history.

\section{Contemporary Studies on Muslims in Muslim Populated Countries}

Contemporary research in anthropology, in the study of religions, and in the social sciences broadens the horizon of research on Muslims living in different areas. These strands of research can therefore be seen as an extension of the sociological and anthropological work of Edvard Westermarck and Hilma Granqvist, even though they did not address political or ideological issues in their research. As against this, recent studies complement research on Islam as a belief system, with their focus on cultural, social, and political factors that along with religion affect people's everyday lives. Thus they do not constitute research on Islam per se, but rather on the plurality of Muslims currently living in a variety of local and increasingly global contexts. In addition to these contextual variations, methodologically this research is often based on ethnographic fieldwork; alternatively, when studying texts, it makes use of recent methods of discourse analysis and rhetorical theory, with an understanding of 'texts' as produced via different media and in different forms, including the Internet. It thus widens the scope of research, from the Qur'an and hadith to all sorts of texts produced by Muslims at different times and places.

With regard to the political factors influencing North Africa and the Middle East, three studies are worth mentioning that shed light on the history and contemporary developments in the countries in these areas. In his work on political development in Algeria from the nineteenth century to the war 
of liberation in 1945, Tuomo Melasuo emphasizes that we need to look at this period of French colonialism in order to understand how cultural identity, including religion, is defined in today's Algeria. Melasuo's work sheds light on the profound changes that European colonialism brought to colonized societies, and on the seeds of unrest that - in his view - are also at the core of contemporary political radicalism. His work does not explicitly address the role of Islam, but helps to understand the historical developments that can lead to the radicalization of Islam as a means of fighting against centralized politics and social problems in the country. (Melasuo 1999.)

Political Islam is a topic explicitly addressed in research on international politics by Aini Linjakumpu and Gubara Said Hassan. Linjakumpu explores the role and place of political Islam on the basis of three case studies, dealing with such diverse issues as Euro-Mediterranean cooperation, the Muslim Brotherhood in Egypt, and the debate over Islam on the Internet. It is obvious that this diversity of cases brings to light the variety of ways in which Islam is practiced and applied today, and how it is defined in different contexts. With this approach, Linjakumpu's study succeeds in dismantling the monolithic picture of Islam that is so persistent in western countries, and shows how Islam is constructed differently at different times and in different places. (Linjakumpu 1999; for a revised version in English, see Linjakumpu 2008.) In a similar vein, Hassan's study shows that so-called 'radical Islam' is not a single, homogeneous phenomenon but consists of diverse movements, organisations and groups, promoting a variety of social, political, economic and moral alternatives based on the Qur'an and the Prophet's tradition in local and international contexts (Hassan 2003). In recent years, several studies on Islam and politics have also dealt with the timely issue of terrorism (see Kivimäki 2005). Indeed, with their emphasis on different constructions of Islam, these studies make clear the problematic nature of any boundaries drawn between religion, culture, and politics, and how difficult it is say where one begins or the other ends. (See Juusola \& Huuhtanen 2002.) With regard to history and politics, other studies worth mentioning are those conducted in the discipline of Development Studies by Holger Weiss, dealing with zakat in pre-colonial Sub-Saharan Africa (2003), and by Pertti Multanen on conflicts in the Middle East (see Raumolin \& Multanen \& Hossain 1998).

In addition to politics, Finnish studies on Islam and Muslims have also investigated gender in such different countries as Turkey, Yemen and Morocco. In Turkey, the position of women has been in the foreground of the political debate at least since the foundation of the Turkish Republic (1923), 
where it has been and continues to be discussed from a variety of ideological viewpoints. In the field of the Study of Religions, Tuula Sakaranaho (1998) has studied different ideological groupings of Turkish women. Based on interviews with Turkish women activists and academics, adhering to secularism, feminism, and Islamism, as well as written sources produced by these women, her study sheds light on the different ways that the development of the women's issue in Turkey is interpreted by these women. In order to analyse complex ideological situations, such as that of contemporary Turkey, Sakaranaho has developed a rhetorical approach that helps to elicit the process by which various positions are constructed and social actors within these standpoints identified. (Sakaranaho 1998; 2008b.) In recent years, the place of Turkey in the European Union has attracted much attention in Finland (Leinonen et al. 2007).

In addition to Turkish women, there is research under way that deals with the contested realities of women and gender relations in other Muslimpopulated societies. In her work in Yemen as a cultural anthropologist, Susanne Dahlgren (2010) has mapped some of the fundamental changes that have taken place during recent decades in the urban setting of Aden, and the significance of these changes for gender relations. With its emphasis on conflicting representations of gender interaction, her work questions previous approaches used in studying Muslim societies, such as Islamic essentialism, the dichotomy of honour vs. shame, the divide between traditional and modern, and, finally, the separate spheres of male and female. Dahlgren (2008) has also edited a special double issue, entitled The Middle Eastern Family Revisited, for Hawwa, Journal of Women of the Middle East and the Islamic World. Finnish research on Islam and gender relations, however, has not focused solely on women. Marko Juntunen (2002) has studied young Moroccan men who earn their livelihood by smuggling people from Morocco to Spain. He examines how these men construct their identity and specifically their masculinity. The men studied by Juntunen are also an interesting case in that as smugglers they are contesting the borders of the European Union. (See also Juntunen 2005.)

Finnish scholars have also studied Muslims in Asian societies. As early as 1984 Seppo Syrjänen wrote his doctoral thesis on Pakistani Muslims who had converted to Christianity. In 1990 Nora Ahlberg (1990) published a study on the religious identity of Pakistani immigrants living in Norway. She first investigated their background in Pakistan, describing the kind of Islam these immigrants had practiced in their home country, and then showed the links between South Asian Islam with the Islam practiced by these people 
in Norway. In the process, she reflected upon Sufism within a local and an international context. In a sense, writing as she was two decades ago Ahlberg was ahead of her time in addressing questions of transnational Islam, which have recently become a timely topic of research (see Nielsen 2003; JEMS 2009).

In addition to these individual studies, the Tampere Peace Research Institute (at the University of Tampere), founded by the Finnish Parliament in 1969 , has played an active role in research on the Mediterranean countries. From 1996 till 2001 the Institute participated in the research program of the European Science Foundation, entitled Individu et société dans le monde méditerranéen musulman, Individual and Society in the Mediterranean Muslim World (ISMMM). In 2007-2010 the Academy of Finland also funded a research project, headed by the University of Joensuu and entitled Making a Good Muslim: Contested Fields of Religious Normativity in the Age of Global Islam; the project covered such countries as Morocco, Egypt, Yemen, Jordan and Indonesia. Its purpose was to investigate the practice of everyday Islam and its individual variations, which often differ from the social norms of the local community. The project thus aimed at balancing the media portrayal of Islam as simply a political issue.

With the exception of a few sporadic studies, practically all Finnish research on various Muslim-populated countries has taken place only since the 1990s. The time gap between the explorations of Westermarck or Granqvist and contemporary scholarship is thus considerable. After all, half a century has elapsed since the work of these pioneers. It is possible to name some reasons for this break in the research tradition. As mentioned above, Edvard Westermarck was somewhat outdated in his approach, which may have discouraged interest in further work in his line of research. Despite academic and financial obstacles, Hilma Granqvist, for her part, continued writing about Palestine well into the 1960s. Because of her lack of a senior academic position, however, she was unable to train a new generation of students who might have followed in her footsteps. Moreover, it is only since the 1970s that the University of Helsinki has had professorships in place in Anthropology and in the Study of Religions. This said, perhaps the expansion of research on Islam since the 1990s can best be explained by the publicity on Islam, and its significance in world politics, which has created a need to study Islam as a religious, cultural and political factor in contemporary societies. Recent Finnish research in different fields of cultural and social studies has aimed at answering this need, to the extent possible given the limited resources of a small country. Indeed, a new challenge faced by research during recent decades is the growth in immigration, which has 
brought Muslims to the doorstep of Finland and has thus stimulated a need to do anthropology here at home.

\section{Anthropology at Home: Muslims in Finland}

The number of foreigners in Finland has grown extensively since the beginning of the $1990 \mathrm{~s}$ as a result of the substantial increase in the number of immigrants and refugees. Traditionally, Finland has been a country of emigration rather immigration but in the past twenty years the situation has changed drastically. The increase in immigration has also had a profound effect on the number of Muslims living in Finland. At the beginning of the 1990s there were some one thousand Muslims in the country; today the number is estimated at around 50,000. Moreover, at the beginning of the 1990s there was only one registered Islamic community founded by immigrants, while today there are around twenty. However, Islam is not something previously unknown in Finland; a small community of Turkish Tatar Muslims have been living here for more than a century. What is new is the visibility of Islam, which has increased with the growing numbers of Muslims coming from the Middle East, North Africa, and Asia. In spite of their low numbers, the Muslim population in Finland is ethnically highly heterogeneous. (See Sakaranaho 2006; Martikainen 2008.)

With the increase in the number of immigrants, research on Muslims in Finland has gradually started to grow. The first joint publication in this field was a collection of articles published in 1999, which brought together scholars from different disciplines (Sakaranaho \& Pesonen 1999). During the next ten years, rapid changes took place in the field of Islam in Finland, which are mapped in the interdisciplinary collection of articles published in 2008 (Martikainen \& Sakaranaho \& Juntunen 2008). These publications suggest that there seem to be two ethnic groups of Muslims that attract particular attention from scholars, i.e. the Turkish Tatars and the Somalis.

The interest in Tatars is understandable, since - as already noted - they have lived in Finland for a considerable time. In addition, they are often referred to as an example of an ethnic and religious minority that is well established and fully integrated into the host society, but that has nevertheless succeeded in keeping vibrant its language, religion, and cultural traditions. At the same time, the number of Tatars is rather small (less than 700), and due to an aging population and the prevalence of mixed marriages it is getting even smaller. Thus the diminishing numbers, together with the process of assimilation, pose a threat to the community. (Halén 1999; Leitzinger 
1996; Leitzinger 2006; Sakaranaho 2002; Sakaranaho 2006, 227-46.) Somalis, numbering around 13,000, constitute the largest single group in Finland among refugees, among immigrants of African origin, and among people of Islamic faith. ${ }^{10}$ Recently, research on the Somalis has become organised into a network, with contacts abroad as well. In comparison to the Tatars, the integration of the Somalis has met with many complications, which is also reflected in research (see Lilius 2001). This research has dealt, among other issues, with the adjustment of Somali women in everyday life and their encounter with the Finnish health care system (Tiilikainen 2003), the adjustment of young Somalis to Finnish schools (Alitolppa-Niitamo 2004), the life of Somali boys in the Helsinki metropolitan area (Hautaniemi 2004), and Somali women and girls at the crossroads of Somali and Finnish culture (Marjeta 2001; Salmela 2004; Niemelä 2003). Thus far there has been very little research on Muslim converts in Finland; a fair idea of their activities, however, can be gained by reading the monthly periodical An-Nur, which has been edited by Isra Lehtinen for over ten years. Besides Somalis, there have been only a few sporadic studies of other ethnic Muslim groups in Finland (see Sakaranaho \& Pesonen 1999; Martikainen 2006; Martikainen \& Sakaranaho \& Juntunen 2008).

In addition to different ethnic groups, one important topic of research since the beginning of the 1990s has focussed on mosques and Islamic associations. This is understandable in Finland, where religious minorities can best avail themselves of their rights through religious associations (see Martikainen 2004; Sakaranaho 2006). Thus Muslims have actively organised themselves in registered Islamic communities and associations in order to gain support in such matters as children's education, social networking, and in particular collaboration with the national and local authorities. The timing and form of recent Muslim organisations resemble those of other immigrant associations in Finland (Pyykkönen 2007; see also Martikainen 2004).

Current research on Muslims in Europe is characterised by certain recurring themes, which emerge in Finnish studies as well (see Sakaranaho 2006, 9-12). One such theme is religious freedom, which due to the rapid cultural and religious pluralisation of European societies is the subject of vigorous debate both in the European Union and in its individual member states (Shahid \& van Koningsveld 1995; 2002). New immigrant countries, such as Finland and the Republic of Ireland, seem to resort to similar methods of dealing with religious pluralism, whereby they extend some of the rights of

$10<$ http://pxweb2.stat.fi/database/StatFin/vrm/vaerak/vaerak_fi.asp > 
a traditionally dominant Christian Church to religious minorities. Thus they keep the status quo intact while at the same time addressing multicultural issues. (See Sakaranaho 2006.) Another fairly rapidly growing field of study concerns the coverage of Islam in the Finnish media. In general the media focus on news concerning Muslims in relation to political events involving problems and violence, thus tending to construct a rather negative image of Islam. In sporadic cases, however, the media cover Muslims in their everyday life, and can thus be seen as some sort of journalism of tolerance. (See Creutz-Kämppi 2008; Maasilta \& Rahkonen \& Raittila 2008; Taira 2008.)

In recent years, one hotly debated topic in Europe has been the teaching of Islam in the schools (see Aslan 2009). In Finland, however, this has been a topic of research already for two decades. At the beginning of the 1990s, the Department of the History of Religion at Åbo Akademi University joined a European project on Islam in school textbooks, initiated in 1988 by the Islamische Wissenschaftliche Akademie in Cologne. The impetus for this project was the negative image that is so often attached to Islam in the European media. Since the schools are such an important mediator of knowledge, this project was founded in order to evaluate how textbooks represent unfamiliar religions and cultures in general and Islam in particular. Altogether twenty European countries took part in the project; the report of the Finnish section was published in 1993, under the title Teaching Islam in Finland (Holm 1993). In addition to this final report, there was also a previous publication in connection with this project, dealing with Islam in the light of research by Finnish and Swedish scholars (Holm 1995). This publication gives an overview of the history of research on Islam, including Wallin, Westermarck, and Granqvist; discusses certain theological issues in comparisons between Islam and Christianity; and addresses certain topical issues, such as the construction of Euro-Islam and Muslim women in migration studies. Together with the Westhill College of Higher Education in the UK, Åbo Akademi University also participated at the end of the 1990s in a research project on multicultural education, entitled Understanding Christianity and Islam in Secular Europe, with the aim of developing methods for multicultural and multireligious teaching as well as enhancing intercultural dialogue. A project report was published in 2000; it contains articles on a wide range of topics on religious education in Finland, Sweden, and Britain. (Holm 2000.)

Teaching Islam in the schools is still a topical issue, which seems to be gaining in importance in an increasingly multicultural Finland. The abovementioned themes concerning Islam, religious and multicultural education 
were also the topic of two recent research projects, administered by the Department of the Study of Religions at the University of Helsinki. The first, entitled 'Muslims and Religious Equality in Finland', was part of the multi-disciplinary 'Research programme on marginalisation, inequality and ethnic relations in Finland' (2001-2003), funded by the Academy of Finland and 'concerned with the mechanisms leading to inequality and marginalisation and with the various related processes, especially with the change in ethnic relations' (www.aka.fi). The purpose of this project was to study the integration of Muslim immigrants in Finnish society and thereby to investigate important factors concerning religion, education, and health that are crucial to this process (see Sakaranaho \& Alitolppa-Niitamo \& Martikainen \& Tiilikainen 2004). The second, two-year project, 'Teachers, religions and multicultural education' (2004-2005) looked at religious and multicultural education in Finland, Poland and Spain; its results were published in 2007 (Sakaranaho \& Jamisto 2007; Sakaranaho 2009).

As long as the Finnish Freedom of Religion Act (2003) and the consequent Education Acts (2003) are in effect, the question of Islamic education remains on the agenda, to be settled one way or another. One especially urgent question is the training of teachers of Islam; such training started at the University of Helsinki in 2007, but it has been very slow to produce results due to the requirement that applicants have to have excellent proficiency in Finnish in order to qualify for a place in teacher training. So far this problem remains unsolved, and teachers of Islam are thus forced to work without an official qualification, as low-salaried, part-time and non-tenured teachers (see Sakaranaho 2006; 2008a; Onniselkä 2011).

The field of education is undoubtedly one of the most important issues in relation to the governance of Islam in Europe. This and other issues are among the topics of the Academy of Finland research project entitled 'The Governance of Transnational Islam: The Case of Finland, Ireland and Canada' (2010-2013), initiated in January 2010 at the University of Helsinki. This project investigates Muslim integration into multicultural western societies, the challenges Islam poses for these societies, and the policies that have been adopted to meet these challenges. In particular, the project studies how transnational Islam shapes the development of minority communities and modes of minority governance in Finland, Ireland, and Canada. Finland and the Republic of Ireland are both EU Member States and post-1980 immigration societies. Canada will serve as a point of comparison, as a major, non-European immigration country with a federal policy of multiculturalism in place since 1971. In this project, transnational Islam is understood, 
first, as an organizing social, religious, gendered and political dimension in the lives of Muslim immigrants (Vertovec 2001), second, as an object of governance by western nation-states (d'Appollonia \& Reich 2008).

All in all, contemporary research on Muslims in Finland, as in other European countries, has had to come to terms with the highly complex questions that arise in a globalizing world in which both people and ideas move about. The new information technology has transformed distance into proximity and the borders of previous nation-states into international networks. As a result of the expanding diaspora, European societies have to decide on their policies concerning multicultural issues, which concern both the newcomers and the host societies. In Finland, this process has fully begun only during recent decades, and the situation is thus highly fluid. The studies referred to here, each in their own way, have successfully captured a particular moment in this constant flow of events and processes.

\section{Concluding Remarks}

Some thirty years ago, Maxime Rodinson (1980) expressed the hope that increased research might deepen our understanding of the Muslim world. Today, this hope may be the same but the scale of what needs to be understood is significantly wider. We are no longer only citizens of our own nations but actors in a globalised world, where the events of 9/11 - and subsequent terrorist attacks in Madrid and London - have profoundly shaken both Muslims and non-Muslims. In this political atmosphere, Islam is often seen as a threat to the security of Western countries and Muslims as a problem for multicultural policies, which according to some leading European politicians have drastically failed. (See JEMS 2007.) This one-sided negative portrayal of Muslims has led some to coin the term 'Islamophobia', understood as another form of the anti-semitism from which Jews have suffered for centuries (see Sayyid \& Vakil 2010). At the other end of the scale, some speak of 'Islamofascism' in describing the politics carried out in the name of Islam. The 'clash of civilizations' predicted by Samuel Huntington (1996) seems to be taking place right under our eyes (see Martikainen \& Sakaranaho 2011; see also Martikainen 2011, 77-80).

As a result of these developments, the dimension of security in relation to Islam and Muslims has become increasingly important in Western countries. What is thus needed, according to Bleich $(2009,354)$, is 'a systematic attempt to review interactions between Muslim minorities and a variety of liberal democratic states in light of the new salience of security concerns'. At the 
same time, Bleich warns against the risk of using security as the primary lens through which to view Muslims, arguing that more comparative research is needed on the relations between Muslims and different states, in a broader context of discussion on integration, race relations, and church-state relations. (Bleich 2009, 354, 359; see also McLoughlin and Zavos, forthcoming).

Moreover, in Europe, where the role of the nation-state is growing weaker and the civil society is gaining in prominence, students of Islam need new conceptual tools in order to explain contemporary phenomena. Studies on transnational Islam, and on different modes of governance in dealing with cultural and religious plurality in Europe, are examples of new avenues for research on Muslims in contemporary society (see Bowen 2004; Bader 2007; Maussen 2007; Martikainen 2007). With respect to Muslims in Europe we are also witnessing a generational shift, leading one to wonder what the future of Islam in Europe will look like. How will this generational shift affect the ways Islam is interpreted and practiced in Europe? How do young Muslims, for instance in Finland, see their role as members of Finnish society and as representatives of Islam within their own communities? A new magazine, Umma, published and edited by young Muslims in Finland ${ }^{11}$ may give some indication. Finnish research has only just started to tackle such questions (see Martikainen \& Haikkola 2010).

The need for an enhanced understanding of Islam would seem to be a pressing issue in Finland; of the ten European countries included in the ISSP2008 survey, Finland scored highest in negative attitudes towards Islam. This may be due at least in part to another finding in the same survey, according to which Finns are in general highly critical of extreme forms of religiosity. (Ketola forthcoming.) Due to the media coverage of Islam as a violent and 'fundamentalist' religion, as noted above, it would come as no surprise if the Finns who took part in the survey envisaged Islam as representative of the religious extremism they oppose. Unfortunately, the survey did not include questions as to national identity; thus it yields no information for instance as to the attitudes of Finns towards 'Finnishness' or their views as to the main signifiers of being a Finn, such as membership in the Lutheran Church. However, in his analysis of the survey, Kimmo Ketola (forthcoming) assumes that the positive attitude of Finns towards their own religion may be due to the fact that in Finland religion is partly intertwined with national identity. His interpretation is in line with the observations of recent studies on religious education in the Nordic countries and Germany,

11 <http://www.sine.fi/ummalehti> 
where along with growing multiculturalism there seems to be a general consensus that it is important to protect a country's national religio-cultural heritage (see Sakaranaho 2006, 350-351). Since Islam is often seen in Europe as a threat, and as the epitome of something which is alien and unacceptable to ' $u s^{\prime}$, the need to protect 'our' national religious and cultural tradition may be related to the negative attitudes expressed towards Islam. At the same time, it is worth noting that the ISSP2008 survey found Ireland, as another small and fairly homogeneous European country, to score very highly not on intolerance but on tolerance towards Islam and other religions as well (see Ketola forthcoming; cf. Sakaranaho 2006, 409-424).

In addition to questions concerning Islam in Europe, as I am writing this, in the spring of 2011, the current demonstrations in Tunis, Egypt and other Arab countries are a truly interesting phenomenon. As noted by Tuomo Melasuo (2011), these demonstrations are motivated by the economic and social frustration of people who are seeking their democratic rights and a better livelihood. In these 'revolutions for respect', Islam does not seem to play a part. The question thus arises whether these demonstrations are indeed a post-Islamist phenomenon, as suggested by the French scholar Oliver Roy in Le Monde, 12 February 2011, and whether the appeal to Islam will gradually be sidelined in the politics of Muslim populated countries (see Melasuo 2011). So far it is too early to say. In any case, these events show the kind of rapid and dynamic developments scholars are faced with; both in the world and in Europe Islam is intertwined with constant social and political changes, making it challenging for research to follow suit. Indeed, it is obvious - whether at the national or the international level, or both that we are dealing with highly complex issues, and that various avenues of research are necessary in order to manage this complexity. 
Bibliography ${ }^{12}$

\section{Aalto, Pentti}

1971 Oriental Studies in Finland 1828-1918. Helsinki: Societas scientiarum Fennica.

\section{Ahlberg, Nora}

1990 New challenges - old strategies: themes of variation and conflict among Pakistani Muslims in Norway. Helsinki: Transactions of the Finnish Anthropological Society.

\section{Akar, Sylvia}

2006 But if you desire God and his messenger: the concept of choice in Sạị alBukhārì. Helsinki: Finnish Oriental Society.

\section{Alitolppa-Niitamo, Anne}

2004 The Icebreakers. Somali-speaking Youth in the Metropolitan Helsinki with a focus on the Context of Formal Education. Helsinki: The Population Research Institute.

\section{Allardt, Erik}

1984 Lukijalle [To the reader]. - Edvard Westermarck [1939], Kristinusko ja moraali [Christianity and morals], 5-8. Helsinki: Otava.

1998 Edvard Westermarck. - Per Schybergson (ed.), Sphinx. Totuuden nimessä. Kaksitoista merkittävää Suomen Tiedeseuran jäsentä [Sphinx. In the name of Truth: Twelve distinguished members of the Societas Scientiarum Fennica], 104-20. Helsinki: Societas Scientiarum Fennica.

\section{Aro, Jussi}

1979 Georg August Wallin ja arabismi [Georg August Wallin and Arabism]. - Suomen Antropologi [Journal of Finnish Anthropology] 4, 33-48.

\section{Aslan, Ednan (Hg.)}

2009 Islamische Erziehung in Europa. Islamic Education in Europe. Wien, Köln, Weimar: Böhlau.

\section{Bader, Veit}

2007 The Governance of Islam in Europe: The Perils of Modelling. - The Journal of Ethnic and Migration Studies, 33 (6), 871-86.

\section{Bleich, Erik}

2009 State Responses to 'Muslim' Violence: A Comparison of Six West European Countries. Journal of Ethnic and Migration Studies 35 (3), 361-79.

12 The titles in Finnish have been translated into English rather freely. 


\section{Bowen, John}

2004 Beyond migration: Islam as a transnational public space. - Journal of Ethnic and Migration Studies, 30 (5), 879-94.

\section{Böre, Z. I. Ahsen}

1942 Minkä tähden halusin toimittaa Koraanin suomeksi [Why I wanted to translate the Qur'an into Finnish]. - Koraani. Opastus ja johdatus pahan hylkäämiseen ja hyvän valitsemiseen [The Qur'an. A guide to avoiding evil and choosing good], 5-6. Tampere: Tampereen Islamin yhdyskunta.

\section{Buijs, Franck J. \& Jan Rath}

2006 Muslims in Europe: The state of research. IMISCOE Working Papers. Amsterdam: IMISCOE.

\section{Creutz-Kämppi, Karin}

2008 Islam Suomen ruotsinkielisissä sanomalehdissä [Islam in Swedishlanguage newspapers in Finland]. - Tuomas Martikainen \& Tuula Sakaranaho \& Marko Juntunen (eds), Islam Suomessa. Muslimit arjessa, mediassa ja yhteiskunnasssa [Islam in Finland: Muslims in everyday life, the media and society], 244-65. Helsinki: Suomalaisen Kirjallisuuden Seura.

\section{Dahlgren, Susanne}

2008 Middle Eastern Family Revisited. - Hawwa, Journal of Women of the Middle East and the Islamic World 6 (1), 1-11 \& (2), 125-128.

2010 Contesting Realities. The Public Sphere and Morality in Southern Yemen. Syracuse: Syracuse University Press.

\section{d'Appollonia, Ariane Chebel \& Simon Reich (eds)}

2008 Immigration, Integration, and Security: America and Europe in Comparative Perspective. Pittsburgh: University of Pittsburgh Press.

\section{Frankenhaeuser, Annika}

1981 Hilma Granqvists betydelse för finländsk antropologi. - Anita KellesViitanen (ed.) Suomalaisen antropologian uranuurtajia [Pioneers of Finnish Anthropology], 44-60. Helsinki: Suomen Antropologinen Seura.

\section{Granqvist, Hilma}

1931 Marriage Conditions in a Palestinian village I. Helsingfors: Finska vetenskapssocieten.

1935 Marriage Conditions in a Palestinian village II. Helsingfors: Societas scientiarum Fennica.

1947 Birth and Childhood among the Arabs. Helsingfors: Söderström.

1950 Child Problems among the Arab: Studies in Muhammedan Village in Palestine. Helsingfors: Söderström.

1965 Muslim Death and Burial: Arab customs and traditions studied in a village in Jordan. Helsinki: Societas Scientiarum Fennica. 


\section{Halén, Harry}

1999 Suomen tataarit [The Finnish Tatars]. - Markku Löytönen \& Laura Kolbe (eds), Suomi. Maa, kansa, kulttuuri [Finland: Land, People, Culture], 315-32. Helsinki: Suomalaisen Kirjallisuuden Seura.

\section{Hallenberg, Helena}

$1997 \mathrm{Ibr}^{-}$ah ${ }^{-} \mathrm{im}$ al_Das${ }^{-} u q^{-} i$ (1255-96): a saint invented, Helsinki: Asian ja Afrikan kielten ja kulttuurien laitos. [Unpublished doctoral dissertation.]

\section{Hallenberg, Helena \& Irmeli Perho}

1992 Heijastuksia valosta: mystikkojen islam [Reflections of the light: Islam of the Mystics]. Helsinki: Yliopistopaino.

\section{Hassan, Gubara Said}

2003 Radical Islam: History, Catalysts, Social Bases and the Ideological Quest for an International Islamic Alternative, Cases from Egypt and the Sudan. Helsinki: University of Helsinki, Department of Political Sciences.

\section{Hautaniemi, Petri}

2004 Pojat! Somalipoikien kiistanalainen nuoruus Suomessa [Boys! The Contested Youth of Somali boys in Finland]. Helsinki: Nuorisotutkimusverkosto, Nuorisotutkimusseura.

\section{Hirvonen, Heidi}

2010 Christian-Muslim Dialogue. Perspective of Four Lebanese Thinkers. Helsinki: University of Helsinki. [Unpublished doctoral dissertation.]

Holm, Nils G. (ed.)

1993 Teaching Islam in Finland. Åbo: Åbo Akademi.

1995 Islam i forskningens ljus. Åbo: Ảbo Akademi.

2000 Islam and Christianity in school religious education: issues, approaches and contexts. Åbo: Åbo Akademi.

\section{House, Jim}

1996 Muslim communities in France. Gerd Nonneman \& Tim Niblock \& Bogdan Szajkowski (eds.), Muslim Communities in the New Europe, 219-240. Reading: Ithaca Press.

\section{Hukari, Ari}

2005 Islam, ilmoitus ja historia: Abdul A'la Mawdudin ja Fazlur Rahmanin Koraanin ja tradition tulkinta [Islam, revelation and history]. Helsinki: Suomalainen Teologinen Kirjallisuusseura.

Hunter, Shireen T. (ed.)

2002 Islam, Europe's Second Religion. The New Social, Cultural, and political Landscape. Westport, Connecticut \& London: Praeger. 


\section{Huntington, Samuel}

1996 (1993) The Clash of Civilisations. - The Clash of civilizations? The Debate, 1-25. New York: Council of Foreign Affairs.

\section{Hämeen-Anttila, Jaakko}

1997a Johdatus Koraaniin [Introduction to the Qur'an]. Helsinki: Gaudeamus. 1997b Koraanin selitysteos [Explanation of the Qur'an]. Helsinki: Basam Books. 1999 Islamin monimuotoisuus [Multifaceted Islam]. Helsinki: Gaudeamus.

2002 Jumalasta juopuneet: Islamin mystiikan käsikirja [Inebriated of God: Handbook of Islamic Mysticism]. Helsinki: Basam Books.

\section{Ihanus, Juhani}

1990 Kadonneet alkuperät: Edvard Westermarckin sosiopsykologinen ajattelu [Origins lost: The sociopsychological thinking of Edvard Westermarck]. Helsinki: Suomen Antropologinen Seura.

\section{Isotalo, Riina}

1995 Edward Westermarck and Hilma Granqvist in the field of Orientalist discourse in Finland. - The third Nordic conference on Middle Eastern Studies: Ethnic encounter and culture change. Joensuu, Finland, 19-22 June 1995. <http://www.smi.uib.no/paj/Isotalo.html> accessed August 26, 2010.

\section{Jeldtoft , Nadja}

2009 On defining Muslims. - Jørgen S. Nielsen et al. (eds), Yearbook of Muslims in Europe, Vol. 1, 9-14. Leiden: Brill

\section{JEMS}

2007 Special Issue: Governing Islam in Western Europe: Essays on Governance of Religious Diversity. - Journal of Ethnic and Migration Studies 33 (6).

2009 Special Issue on Muslim and the state after 9/11. - Journal of Ethnic and Migration Studies 35 (3).

\section{Juntunen, Marko}

2002 Between Morocco and Spain: men, migrants and a dispersed Moroccan community. Helsinki: University of Helsinki. <http://ethesis.helsinki. fi/julkaisut/hum/aasia/vk/juntunen>

2005 Islamin arki: maailma marokkolaisen silmin [The Everyday Life of Islam: the world with the eyes of a Moroccan]. Helsinki: Ajatus.

\section{Juusola, Hannu}

2011 Miten Lähi-itää tulisi tutkia? Lähi-idän tutkimus orientalismin ja aluetutkimuskritiikin välissä [How to study the Middle East: Research on the Middle East in between Orientalism and the critique of Area Studies]. - Tieteessä tapahtuu 2, 17-22. 


\section{Juusola, Hannu \& Heidi Huuhtanen (eds)}

2002 Uskonto ja politiikka Lähi-idässä [Religion and Politics in the Middle East]. Helsinki: Gaudeamus.

\section{Kantokorpi, Otso}

1984 Matkakirja kulttuurin tulkkina - omansa vai vieraan? [Travelbook as an interpreter of a culture - whether one's own or that of the stranger] - Tuomo Melasuo (ed.), Wallinista Wideriin. Suomalaisen kolmannen maailman tutkimuksen perinteitä [From Wallin to Wider: The traditions of Finnish third-world research], 223-39. Tampere: Suomen Rauhantutkimusyhdistys.

\section{Ketola, Kimmo}

forthcoming Suomalaisten uskonnollinen suvaitsevaisuus [The religious tolerance of the Finns]. - Kimmo Ketola \& Kati Niemelä \& Harri Palmu \& Hanna Salomäki, Uskonnollisuus ja uskonnon merkitys 2000-luvulla: Uskonto kansainvälisessä ISSP2008-tutkimuksessa [Religion and the significance of religion in the 21st Century: Religion in the international ISSP2008 survey]. Tampere: Yhteiskuntatieteellinen tietoarkisto (FSD).

\section{Kivimäki, Timo (ed.)}

2005 Islam, the West, and Violence: Sources, Catalysts, and Preventive Measures. Helsinki: Ministry for Foreign Affairs, Development Policy Information Unit.

\section{Kähkönen, Esko S.}

2000 Dialogisuuden ongelma islamin esittämisessä: Falaturin ja Tworuschkan teologis-pedagogisen ohjelman tausta ja toteutuminen [The problem of dialogue in the presentation of Islam: Background and implementation of the theological and pedagogical program of Falaturi and Tworuschka]. Helsinki: Suomalainen teologinen kirjallisuuseura.

\section{Laitila, Teuvo}

2001 Soldier, structure and the other: social relations and cultural categorisation in the memoirs of Finnish guardsmen taking part in the Russo-Turkish war, 1877-1878. Helsinki: Department of Anthropology.

\section{Leitzinger, Antero}

1996 Mishäärit: Suomen vanha islamilainen yhteisö [The Mishäärs: An old Islamic community in Finland]. Helsinki: Kirja-Leitzinger.

2006 Suomen tataarit: vuosina 1868-1944 muodostuneen muslimiyhteisön menestystarina [Finnish Tatars; the success story of a Muslim community formed between 1868 and 1994]. Helsinki: East-West Books.

\section{Leinonen, Anu \& Tuula Kojo \& Mervi Nousiainen \& Sampsa Peltonen \& Lauri Tainio (eds)}

2007 Turkki - Euroopan rajalla? [Turkey: at the edge of Europe?] Helsinki: Gaudeamus Helsinki University Press. 
Lilius, Muddle Suzanne (ed.)

2001 Variations on the Theme of Somaliness. Turku: Åbo Akademi University, Centre for Continuing Education.

\section{Linjakumpu, Aini}

1999 Polittinen islam [Political Islam]. Helsinki: Like.

2008 Political Islam in the Global World. Reading: Ithaca Press.

Maasilta, Mari \& Juho Rahkonen \& Pentti Raittila

2008 Islam suomalaisissa joukkoviestimissä [Islam in the Finnish Media]. Tampere: Tampereen yliopisto, Tiedotusopin laitos.

Malinowski, Bronislaw

1960 (1944) A Scientific Theory of Culture and Other Essays. New York: Oxford University Press.

Maréchal, Brigitte

2003 The Question of Belonging. - Brigitte Maréchal \& Stefano Allievi \& Felice Dassetto \& Jørgen Nielsen (eds), Muslims in the Enlarged Europe. Religion and Society, 5-18. Leiden, Boston: Brill.

Maréchal, Brigitte \& Stefano Allievi \& Felice Dassetto \& Jørgen Nielsen (eds)

2003 Muslims in the Enlarged Europe. Religion and Society. Leiden, Boston: Brill.

\section{Marjeta, Maarit}

2001 Äidit ja tyttäret kahdessa kulttuurissa: Somalialaisnaiset, perhe ja muutos [Mothers and daughters in two cultures: Somali women, family and change]. Joensuu: Joensuun yliopisto, Sosiologian laitos.

\section{Martikainen, Tuomas}

2004 Immigrant Religions in Local Society: Historical and Contemporary Perspectives in the City of Turku. Åbo: Âbo Akademi.

2007 The Governance of Islam in Finland. - Temenos 43 (2), 243-65.

2008 Muslimit suomalaissa yhteiskunnassa [Muslims in Finnish society]. - Tuomas Martikainen \& Tuula Sakaranaho \& Marko Juntunen (eds), Islam Suomessa. Muslimit arjessa, mediassa ja yhteiskunnassa [Islam in Finland. Muslims in everyday life, the media and society], 62-84. Helsinki: Suomalaisen Kirjallisuuden Seura.

2011 Suomi Remix [Finland Remix]. Helsinki: Like.

Martikainen, Tuomas (ed.)

2006 Mirajainen kulttuuri: Etnisyys Suomessa 2000-luvulla [Transnational culture: Ethnicity in Finland in the 2000s]. Helsinki: Suomalaisen Kirjallisuuden Seura. 


\section{Martikainen, Tuomas \& Tuula Sakaranaho \& Marko Juntunen (eds)}

2008 Islam Suomessa. Muslimit arjessa, mediassa ja yhteiskunnassa [Islam in Finland. Muslims in everyday life, the media and society]. Helsinki: Suomalaisen Kirjallisuuden Seura.

\section{Martikainen, Tuomas \& Lotta Haikkola (eds)}

2010 Maahanmuutto ja sukupolvet [Immigration and generations]. Helsinki: Suomalaisen Kirjallisuuden Seura.

Martikainen, Tuomas \& Tuula Sakaranaho (eds)

2011 Mitä muslimit tarkoittavat? Keskustelua islamin virtauksista Suomessa ja Euroopassa. [What do Muslims mean? Discussion on Islamic trends in Finland and Europe]. Helsinki: Savukeidas.

\section{Maussen, Marcel}

2007 The Governance of Islam in Western Europe: A State of the Art Report. IMISCOE Working Paper. Amsterdam: IMISCOE.

\section{McLoughlin, S. \& J. Zavos}

Forthcoming Writing Religion in British Asian Diasporas. - S. McLoughlin \& W. Gould \& A. Kabir \& E. Tomalin (eds), Writing the City in British Asian Diasporas. London and New York: Routledge (2011).

\section{Mead, William Richard}

1958 G. A. Wallin and the Royal Geographical Society. Helsinki: Societas Orientalis Fennica.

1979 Georg August Wallin: the English Connection. - G. A. Wallin, Travels in Arabia (1845 and 1848), vii-xv. Cambridge: Falcon-Oleander.

\section{Melasuo, Tuomo}

1993 Review of Finnish Literature on Islam. - Nils G. Holm (ed.), Teaching Islam in Finland, 29-50. Åbo: Åbo Akademi.

1995 Bilden av Marocko hos Edvard Westermarck. - Nils G. Holm (ed.), Islam i forskningens ljus, 45-81. Åbo: Åbo Akademi.

1999 Algerian poliittinen kehitys 1800-luvulta vapautussotaan 1945 [The Political development of Algeria from the 19th century to the war of liberation in 1945]. Tampere: Rauhan- ja konfliktintutkimuskeskus.

2011 Politikointia islamilla [Doing politics with Islam]. - Tuomas Martikainen \& Tuula Sakaranaho (eds), Mitä muslimit tarkoittavat? Keskustelua islamin virtauksista Suomessa ja Euroopassa. [What do Muslims mean? Discussion on Islamic trends in Finland and Europe], 45-63. Helsinki: Savukeidas.

\section{Nielsen, Jørgen}

1995 (1992) Muslims in Western Europe. Edinburgh: Edinburg University Press. 
2003 Transnational Islam and the integration of Islam in Europe. - Stefano Allievi \& Jørgen Nielsen (eds), Muslim Networks and Transnational Communities in and across Europe, 28-51. Leiden, Boston: Brill.

\section{Niemelä, Heli}

2003 Erottautumista ja ystävyyttä: Somalialaistyttöjen käsityksiä ja kokemuksia suomalaisista tytöistä [Separations and friendships: Somali girls' impressions and experience of Finnish girls]. - Päivi Harinen (ed.), Kamppailuja jäsenyyksistä: Etnisyys, kulttuuri ja kansalaisuus nuorten arjessa [Contested memberships: Ethnicity, culture and citizenship], 91-121. Helsinki: Nuorisotutkimusverkosto.

\section{Nisula, Tapio}

1994 Uranuurtajia ja myyttejä: antropologisen kenttätyön historiaa [Pioneers and myths: On the history of anthropological fieldwork]. Tapio Nisula (ed.), Näköaloja kulttuureihin - antropologian historiaa ja nykysuuntauksia [Perspectives on cultures: Anthropology past and present], 221-40. Tampere: Suomen Antropologinen Seura.

\section{Numelin, Ragnar}

1941 Edvard Westermarck and the Finnish Sociological School. - Le Nord - Revue Internationale des Pays du Nord, iv, 268-82.

\section{Onniselkä, Suaad}

2011 Islamin opetus koulussa [Islamic education at school]. - Tuomas Martikainen \& Tuula Sakaranaho (eds), Mitä muslimit tarkoittavat? Keskustelua islamin virtauksista Suomessa ja Euroopassa. [What do Muslims mean? Discussions on the Islamic trends in Finland and Europe], 122-38. Helsinki: Savukeidas.

\section{Palva, Heikki}

1995 Arabisk-islamisk litteratur: Utvecklingslinjer och särdrag. - Nils G. Holm (ed.), Islam i forskningens ljus, 215-30. Åbo: Ảbo Akademi.

2001 Arab Studies in Finland since the Seventeenth Century. Vantaa: Proceedings of the Finnish Institute in the Middle East.

Palva, Heikki \& Irmeli Perho (eds)

1998 Islamilainen kulttuuri [Islamic culture]. Helsinki: Otava.

\section{Perho, Irmeli}

1995 The Prophet's Medicine: A Creation of the Muslim Traditionalist Scholars. Helsinki: The Finnish Oriental Society.

\section{Pipping, Knut}

1982 The First Finnish Sociologist: A Reappraisal of Edward Westermarck's Work. - Acta Sociologica 25 (4), 347-57. 


\section{Pyykkönen, Miikka}

2007 Järjestäytyvät diasporat: Etnisyys, kansalaisuus, integraatio ja hallinta maahanmuuttajien yhdistystoiminnassa [Organising diasporas: Ethnicity, citizenship, integration and governance in immigrant associations]. Jyväskylä: Jyväskylän yliopisto.

\section{Raumolin, Jussi \& Pertti Multanen \& Masud Hossain}

1998 Uskonnolliset ja etniset tekijät kansainvälisissä konflikteissa ja politiikkatavoitteissa: Balkanin niemimaa, Lähi-itä ja Etelä-Asia [Religious and ethnic factors in international conflicts and political aims: The Balkans, the Middle East and South Asia]. Helsinki: Kehitysmaatutkimuksen laitos.

Rippin, Andrew (eds)

2006 Defining Islam: A Reader. London: Equinox.

\section{Rissanen, Seppo}

1977 Hilma Granqvist - suomalainen kulttuuriantropologi [Hilma Granqvist: a Finnish cultural anthropologist]. - Suomen Antropologi, 39-41.

1993 Theological encounter of oriental Christians with Islam during early Abbasid rule. Åbo: Åbo Akademis förlag.

\section{Rodinson, Maxime}

1980 La fascination de l'Islam. Paris: Maspero.

\section{Räisänen, Heikki}

1971 Das koranische Jesusbild: ein Beitrag zur Theologie des Korans. Helsinki: Missiologian ja ekumeniikan seura.

1972 The idea of divine hardening: a comparative study of the notion of divine hardening, leading astray and inciting to evil in the Bible and the Qur'an. Helsinki: Finnish Exegetical Society.

1986 Koraani ja Raamattu [The Qur'an and the Bible]. Helsinki: Gaudeamus.

1997 Marcion, Muhammad and the Mahatma: Exegetical perspectives on the encounter of cultures and faiths. London: SCM Press.

\section{Sakaranaho, Tuula}

1998 The Complex Other: a rhetorical approach to women, Islam, and ideologies in Turkey. Comparative Religion 3. Helsinki: University of Helsinki, Department of Comparative Religion.

2003 Des Déserts aux faubourgs d'Helsinki: travaux finlandais sur les peoples musulmans - Ethnologie française XXXIII (2), 271-9.

2002 Kansamme tuntematon väestönosa. Suomalaisten tataarimuslimien julkisuuskuva [An unknown part of our population. The public image of Finnish Tatar Muslims]. - Tuula Sakaranaho \& Heikki Pesonen (eds), Uskonto, julkisuus ja muuttuva yhteiskunta [Religion, the public sphere, and changing society], 133-60. Helsinki: Yliopistopaino. 
2006 Religious freedom, Multiculturalism, Islam. Cross-reading Finland and Ireland. Leiden, Boston: Brill.

2008a Arabian aavikoilta Helsingin lähiöihin. Suomalaisen islamin tutkimuksen näkökulmia [From the Arabian deserts to the suburbs of Helsinki; Perspectives on Finnish Research on Islam]. - Tuomas Martikainen \& Tuula Sakaranaho \& Marko Juntunen (eds), Islam Suomessa. Muslimit arjessa, mediassa ja yhteiskunnassa [Islam in Finland: Muslims in everyday life, the media and society], 11-36. Helsinki: Suomalaisen Kirjallisuuden Seura.

2008 b 'Equal but different': Women in Turkey from the Islamic point of view. - Anitta Kynsilehto (ed.), Islamic feminism: Current perspectives, 47-56. Tampere: Tampere Peace Research Institute.

2009 Constructing Islamic Identity: The Education of Islam in Finnish State Schools. - Ednan Aslan (ed.) Islamische Erziehung in Europa - Islamic Education in Europe, 109-29. Vienna: Böhlau Verlag.

Sakaranaho, Tuula \& Heikki Pesonen (eds)

1999 Muslimit Suomessa [Muslims in Finland]. Helsinki: Yliopistopaino.

\section{Sakaranaho, Tuula \& Anne Alitolppa-Niitamo \& Tuomas Martikainen \& Marja Tiilikainen}

2004 Religion in Migration: Studies on Muslims in Finland. - Vesa Puuronen \& Antti Häkkinen \& Anu Pylkkänen \& Tom Sandlund \& Reetta Toivanen (eds), New Challenges for the Welfare Society, 124-39. Joensuu: Karelian Institute.

\section{Sakaranaho, Tuula \& Annukka Jamisto (eds)}

2007 Monikulttuurisuus ja uudistuva katsomusaineiden opetus [Multiculturalism and reforming religious education]. (Uskontotiede 11.) Helsinki: Helsingin yliopisto, Uskontotieteen laitos.

\section{Salmela, Anu}

2004 Pysyvyyttä muutoksessa ja muutosta pysyvyydessä: Turussa asuvat somalinaiset islamin ja yhteisöperinteen välittäjinä [Permanence in change and change in permanence: Somali women living in Turku as mediators of Islam and communal traditions]. - Outi Fingerroos \& Minna Opas \& Teemu Taira (eds) Uskonnon paikka: Kirjoituksia uskontojen ja uskontoteorioiden rajoista [The Place of Religion: Writings on the Borders of Religions and Theories of Religion], 279-311 Helsinki: Suomalaisen Kirjallisuuden Seura.

Sayyid, S. \& AbdoolKarim Vakil (eds)

2010 Thinking through Islamophobia: Global perspective. London: Hurts \& Company.

\section{Seger, Karen (ed.)}

1981 Portrait of a Palestinian village: the photographs of Hilma Granquist. London : The Third World Centre for Research and Publishing. 


\section{Shahid, W. A. R. \& P. S. van Koningsveld}

1995 Religious Freedom and the Position of Islam in Western Europe. Opportunities and obstacles in the acquisition of equal rights. Kampen: KokPharos.

Shahid, W. A. R. \& P. S. van Koningsveld (eds)

2002 Religious Freedom and the Neutrality of the State: The Position of Islam in the European Union, Leuven, Paris, Sterling: Peeters.

\section{Siikala, Jukka}

1998 Introduction: Ancestral Images and the Invention of New Ideas. - Jukka Siikala \& Ulla Vuorela \& Tapio Nisula (eds), Developing anthropological ideas: the Edward Westermarck memorial lectures 1983-1997, 7-13. Helsinki, The Finnish Anthropological Society.

\section{Smart, Ninian}

1998 The World's Religions. Cambridge: Cambridge University Press.

\section{Stroup, Timothy}

1982 Introduction. - Timothy Stroup (ed.), Edward Westermarck: Essays on His Life and Works, ix-xvii. Helsinki: Societas Philosophica Fennica.

\section{Suolinna, Kirsti \& Catherine af Hällström \& Tommy Lahtinen}

2000 Portraying Morocco: Edward Westermarck's Fieldwork and Photographs 1898-1913. Åbo: Åbo Akademis förlag.

\section{Syrjänen, Seppo}

1984 In Search of Meaning and Identity: Conversion to Christianity in Pakistani Muslim Culture. Helsinki: Missiologian ja ekumeniikan seura.

\section{Säävälä, Minna}

2008 Islam Kosovosta Suomen muuttaneiden naisten elämässä [Islam in the lives of Kosovo women in Finland]. - Tuomas Martikainen \& Tuula Sakaranaho \& Marko Juntunen (eds), Islam Suomessa. Muslimit arjessa, mediassa ja yhteiskunnasssa [Islam in Finland: Muslims in everyday life, the media and society], 111-31. Helsinki: Suomalaisen Kirjallisuuden Seura.

\section{Taira, Teemu}

2008 Islamin muuttuva julkisuuskuva. Tapaustutkimus Helsingin Sanomista 1946-1994. [The changing public image of Islam: A case study of Helsingin Sanomat, 1946-1994. - Tuomas Martikainen \& Tuula Sakaranaho \& Marko Juntunen (eds), Islam Suomessa. Muslimit arjessa, mediassa ja yhteiskunnasssa [Islam in Finland. Muslims in everyday life, the media and society], 200-23. Helsinki: Suomalaisen Kirjallisuuden Seura.

\section{Tiilikainen, Marja}

2003 Arjen islam: Somalinaisten elämää Suomessa [Everyday Islam: The Life of Somali Women in Finland]. Tampere: Vastapaino. 


\section{Urubshurow, Victoria Kennick}

2008 Introducing World Religions. New York and London: Routledge.

\section{Vertovec, Steven}

2001 Transnationalism and Identity. - Journal of Ethnic and Migration Studies $27(4), 573-82$.

\section{Waines, David}

2002 Islam. - Linda Woodhead \& Paul Fletcher \& Hiroko Kawanami \& David Smith (eds), Religions in the Modern World: Traditions and transformations, 182-203. London \& New York: Routledge.

Weir, Shelagh G.

1972 Hilma Granqvist. - Sosiologia 9, 233-5.

Weiss, Holger

2003 Obligatory almsgiving: an inquiry into Zakāt in the pre-colonial Bilād alSūdān. Helsinki: Studia Orientalia.

\section{Westermarck, Edvard}

1891 History of Human Marriage. London: Macmillan.

1906-08 Origin and Development of the Moral Ideas I - II. London: Macmillan.

1914 Marriage Ceremonies in Morocco. London: Macmillan.

1926 Ritual and Belief in Morocco I-II. London: Macmillan.

1930 Wit and Wisdom in Morocco: A Study of Native Proverbs. With the Assistance of Shereef `Abd-Es-Salam El-Baqqali. London: Routledge.

1932 Ethical Relativity. London: Paul Kegan.

1932 Early Beliefs and Their Social Influence. London: Macmillan.

1937 Mohammedan Marriage Customs. Review of Hilma Granqvist, Marriage Conditions in a Palestinian Village. - Nature 139 (3506), 49-50.

\section{Widén, Solveig}

1995 Hilma Granqvist som kvinnohistorier. - Nils G. Holm (ed.), Islam i forskningens ljus, 83-103. Åbo: Åbo Akademi.

\section{Wright, Georg Henrik von}

1982 The Origin and Development of Westermarck's Moral Philosophy. Timothy Stroup (ed.), Edward Westermarck: Essays on his life and works, 25-61. Helsinki: The Philosophical Society of Finland.

\section{Öhrnberg, Kaj}

1983 The offspring of Fātima: dispersal and ramification. Helsinki: The Finnish Oriental Society.

1987 Klassinen orientalistiikka: Itä päiväunena [Classic Orientalism: The East as a day dream]. - Tuomo Melasuo (ed.), Wallinista Wideriin. Suomalaisen kolmannen mailman tutkimuksen perinteitä [From Wallin to Wider: The traditions of Finnish third world research], 23-55. Tampere: Suomen Rauhantutkimusyhdistys. 
1993 Arab and Islamic Studies in Finland. - Nils G. Holm (ed.), Teaching Islam in Finland, 21-8. Åbo: Åbo Akademi.

1995 Den överdrivne älskaren: Georg August Wallin i Arabien. - Nils G. Holm (ed.), Islam i forskningens ljus, 19-43. Åbo: Åbo Akademi.

\section{Öhrnberg, Kaj \& Patricia Berg \& Kira Pihlflyckt}

2010 Georg August Wallin. Skrifter: band 1: studiearen och resan till Alexandria. Helsinki: Svenska litteraturssällskapet in Finland. 
